instruments. Seismic data thus obtained, together with the instrumental data from Colombo, Dehra Dun and Hyderabad Observatories, thanks to the co-operation of the Directors of these Observatories, are collected and edited at the Meteorological Office, Poona. At Poona also are collected and edited the non-instrumental earthquake data reported from time to time. From January 1948 a monthly seismological bulletin has been issued, and the latest to be received is for December 1949. The greatest numbers of earthquakes felt by observers during December 1949 were three at Darjeeling and three at Tezpur, all having an intensity 5 on the RossiFore' scale.

\section{Illuminating Engineering Society}

Mr. I. J. Davies, director of the Research Laboratory of the British Thomson-Houston Company, Ltd., has been elected president for 1950-51 of the Illuminating Engineering Society. The Leon Gaster Memorial Premium (of 10 guineas), which is for the best contribution published by the Society during the year, has been awarded to Dr. R. G. Hopkinson and Mr. P. Petherbridge (both of the Building Research Station, Garston, near Watford), for their paper entitled "Discomfort Glare in Relation to the Lighting of Buildings". The Silver Jubilee Commemoration Award (of 5 guineas) has been given to $\mathrm{Mr}$. I. $\mathrm{H}$. Hall, of Birmingham, for an essay entitled "Some Problems Associated with the Development of the Fluorescent Lamp". This is the first occasion on which this has been awarded for several years; it is open only to members of the Society under the age of twenty-five years for a paper on some aspect of illuminating engineering.

\section{Public Works and Municipal Services Congress and Exhibition}

The Public Works and Municipal Services Congress and Exhibition for 1950 will be held in the Olympia, London, W.14, during November 13-18. The opening ceremony will be performed by Mr. Aneurin Bevan, Minister of Health and president of the Congress and Exhibition Council. A number of conferences, each one under the auspices of a particular organisation, have been arranged in connexion with the Congress, and these organisations are: the Association of Public Lighting Engineers, Institution of Municipal Engineers, Institution of Gas Engineers, County Surveyors Society, County Land Agents Association, Institution of Civil Engineers, Institute of Park Administration (Inc.), British Waterworks Association, Town Planning Institute, Institute of Sewage Purification, Institute of Public Cleansing and the Royal Institute of British Architects. Further details can be obtained from the secretary of the Public Works and Municipal Services Congress, 84 Eccleston Square, London, S.W.I.

\section{Announcements}

Prof. ANDré Mayer, professor of natural history in the College de France, has been elected member of the Section of Rural Economy and Veterinary Practice of the Paris Academy of Sciences, in succession to the late Prof. R. Fosse.

Mr. A. P. C. Cumming has been elected to a Salters' Fellowship for research in chemical engineering during the year 1950-51.

Mr. G. H. NooRDHor has been appointed a lecturer in the Department of Education of the International
Wool Secretariat. Mr. Noordhof is a graduate of the Universities of Cambridge and London, and has carried out research for the Department of Scientific and Industrial Research in the field of physical chemistry.

THE following appointments in the National Agricultural Advisory Service of Britain have recently been announced: Mr. H. L. Shrimpton, deputy chief livestock husbandry officer, to be chief livestock husbandry officer in the Service in succession to Mr. H. Twinch, who has retired; Mr. H. Trefor Jones, provincial soils chemist in the Yorkshire and Lancashire Province of the Service, to be deputy provincial director for the Yorkshire and Lancashire Province in succession to Mr. W. Weir, who has retired.

THE British Standards Institution has opened a branch office at 12 Hilton Street, Manchester, 1, in charge of Mr. A. F. B. Nall, an assistant technical director of the Institution (telephone: Central 4856; telegrams: Bristandin, Manchester). At this office a complete set of British Standards, some 1,600 in number, may be consulted and copies purchased.

THE fifth of the series of Oxford Management Conferences, under the auspices of the British Institute of Management (Management House, 8 Hill Street, London, W.1), will be held at Harrogate during November 16-19. Sectional meetings will be divided into two types: panel debate, in which broad issues will be considered, without advance circulation of the papers; and discussion sessions, in which specific issues will be discussed in considerable detail, with the idea of reaching definite conclusions, and in which the papers will be circulated in advance.

The Royal Society of New Zealand is offering the T. K. Sidey Summer-Time Award, consisting of a bronze medal and a prize of $£ 100$ (N.Z. currency). This award is to be made primarily (though not necessarily) to a New Zealand citizen, or scientific worker in New Zealand, for research on light visible and invisible and other solar radiations in relation to human welfare, or on electromagnetic radiations of every kind. Further information can be obtained from the secretary of the Royal Society of New Zealand, Victoria University College, Wellington, New Zealand.

THE Sintered Oxides Sub-Committee of the InterService Metallurgical Research Council (Ministry of Supply and Admiralty) has recently, in consultation with manufacturers, standardized the production of tubes of special refractory to two materials-impervious alumina and impervious mullite (for use up to $1,700^{\circ}$ C.) - with eight sizes in the range of internal diameters $5-75 \mathrm{~mm}$. and corresponding wall thicknesses of $1 \cdot 5-5 \cdot 5 \mathrm{~mm}$. All standard tubes will be available in lengths up to $900 \mathrm{~mm}$. with both ends open, or one open and the other hemispherically closed. At the same time a standard cross-section of impervious alumina twin-bore thermocouple insulator has been agreed upon.

ERRatum. In the communication "Runs Up and Down on a Lattice" by Prof. P. V. Krishna Iyer in Nature of August 12, p. 276, for "Variance for (1) and (2) ..." read

$$
\left.\begin{array}{l}
\text { "Variance for } \\
\text { (1) and }(2)
\end{array}\right\}=\frac{1}{90}\left\{16 n\left(1^{n}\right)-29\left(1^{n-1}\right)\right\},
$$

where $\left(1^{r}\right)$ denotes the monomial symmetric function of degree $r$ in $l_{1}, l_{2}, \ldots . l_{n}$ ". 